\title{
Sawmilling in Sweden: Past, present and future
}

\author{
Rijan Tamrakar ${ }^{1}$ \\ Email: rijantamrakar@gmail.com
}

\begin{abstract}
With $62 \%$ of her land covered with forest, Sweden is the world's second largest combined exporter of paper, pulp and sawn wood products. Modern industrial sawmilling of Sweden started from the mid-19 ${ }^{\text {th }}$ Century after British import was made liberal, and Norwegian exporters faced short supplies of raw materials and Canadian producers were more expensive. During the same time, Sweden also developed industries and technology making it more competitive. However, after $20^{\text {th }}$ century, sawmilling in Sweden started to adopt 'integrated forest firm approach' where many small and locals sawmills were forced out of the business because of numerous war-crises and oil-crises that occurred. In recent decades production and exports from Sweden is in increasing trend. This increasing trend is the result of some specific strategies undertaken by Swedish sawmilling sectors viz. transforming market channel, transforming product value adding strategy and transforming service value adding strategy. Currently, Swedish sawmills can be categorized into nine groups based on their value addition strategy and technology they use. These sawmills face competition from other materials and countries, low efficient transfer of technology and knowledge transfer, presence of small scale sawmilling, and some sawmills are in risk as they lack of product diversification and have specialized production. Future of the sawmilling in Sweden is expected to be growing. However, they have to encourage the use of wood, transfer skill and knowledge, increase the size of the firm, further diversify the products, and also improve technology and mechanization.
\end{abstract}

Key Words: Sweden, Sawmills, Industries, Production, Technology

\section{Introduction}

About $62 \%$ of Sweden's territory is covered with forest (28 million ha) and 7\% with other wooded land (3 million ha) (FAO, 2010). With this huge forest resources, pulp, paper and sawn wood products have been among the most important Swedish exports for nearly 150 years, and it is likely that they will continue to be important also in the future, in spite of

1 MSc, Environmental Forestry, Bangor University, Sweden 
the many challenges that forest industry face.It is the world's second largest combined exporter of paper, pulp and sawn wood products. It produces about $6 \%$ of the world's sawn timber products and its exports amounts to $12.5 \%$ of global export, and most of its products are exported to UK, Egypt and Germany (Skogs industrierna, 2010). This paper will focus on development of sawmilling industries in Sweden; itspresent strategies and types; major challenges they are facing; and finally its future.

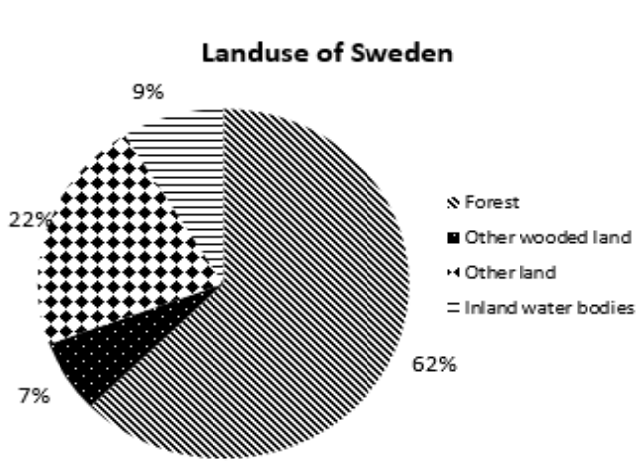

Figure 1: Pie chart showing the Sweden's land use.

\section{History of sawmilling industries in Sweden}

The history of Swedish sawmilling can be studied in two phases. The initial phase from 1850 to 1900 began with the establishment and eventually making it a big export sector by the end of century. Similarly phase from 1900 to 1990 face several crises like wars, oil crisis and competition from paper and pulp which compelled it to undertake strategies of integrated firms for its existence.

\section{Phase 1850-1900}

Sawmilling industries is one of the earliest and important industries for Sweden to metamorphose itself from a being one of the poorest country in the Europe to one of the richest and most advanced economies of the world. Sawmilling is one of the industries that fuelled the growth of Swedish Industries at the early stages. Before 1850, Swedish sawn wood was facing high competition with Norwegian sawmills and worsened by British Navigation Acts that favoured Canadian products. But with the liberalization of British imports in 1850, Sweden became the major supplier of sawn wood as Norwegian exporters faced short supplies of raw materials and Canadian producers were more expensive because of the longer transports (Blomsrom \& Ari, 2002). During the same time, steampowered sawmills were established, industry's technology development undertook utilizing Norwegian firms and technicians which became possible with the investment capital raised from England (Larson, 1991). In fact, several Norwegian firms moved to Sweden, because of the dwindling forest supplies in Norway. As a consequence, exports of sawn wood increased from less than $200,000 \mathrm{~m}^{3}$ in the 1830 s to $4,800,000 \mathrm{~m}^{3}$ at the end of the century. In the 1870s, wood products had grown to make up 43 percent of Swedish exports (Hallvarsson, 1980). The development of the Swedish railway network during the 1860s and 1870s had a stronger impact on the industry, since it facilitated the establishment of many new sawmills in the inner parts of the country. Hence, the sawmill industry expanded rapidly in the eastern and northern parts of Sweden during the 1860s and 1870s, but growth slowed down during the 1890s. The main reason was a shortage of raw material. From the 1860s, sawmills had to compete with the paper and pulp industry for raw material. 


\section{Phase 1900-1990}

During the inter-war period sawmilling industries faced severe crisis resulting in restructuring of industries. Small firms were forced to move out of the business and larger firms took "integrated forest firm approach" operating - pulp and paper, timber, sawn wood, boards, and so forth in late 1920s. Again, a short upturn in prices and exports during the early 1950s was followed a stagnant development until the mid-1960s. During this time also many of the remaining local sawmills were again forced out of business, and there was some concentration in the industry. However, larger firms that undertook integrated approach remained largely intact. By the mid-1960s, the largest producers of sawn wood were Svenska Cellulosa Aktiebolaget (SCA) Company and the state owned company ASSI. During the mid-1960s industries led to large productivity through mechanization and rationalization of operations.

However, the boom ended with the first oil crisis, and the development of prices was largely negative during the mid-1970s. The companies with small own holdings of forest were hardest hit by the recession: forest owners were simply not willing to sell raw material, although timber prices did not fall at the same rate as prices for finished products (Blomsrom \& Ari, 2002). Table 1 show the decrease in number of sawmills but increase in their capacity. The situation did not improve until the early 1980s, with the upturn in the international business cycle. Since 1980s, the sawmilling industries seeking new strategies for their survival started to increase the degree of processing and value addition to the final products.

Table 1: Structural change in sawmill industry 1960-1993

\begin{tabular}{|l|l|l|l|l|}
\hline \multicolumn{1}{|c|}{ Details } & \multicolumn{1}{|c|}{$\mathbf{1 9 6 0}$} & \multicolumn{1}{|c|}{$\mathbf{1 9 7 0}$} & \multicolumn{1}{|c|}{$\mathbf{1 9 8 0}$} & \multicolumn{1}{|c|}{1993} \\
\hline Number of mills (approx.) & 6,500 & 4,000 & 2,400 & 2,500 \\
\hline Capacity per mill (m3, approx.) & 1,200 & 3,800 & 4,500 & 5,000 \\
\hline
\end{tabular}

Source: Svensén (1992), Skogsindustrierna (1994)

\section{Swedish sawmilling in recent decades}

As shown in figure 2, production of sawn wood products are in increasing trends, Sweden produced about 17 million $\mathrm{m}^{3}$ of sawn wood products in year 2010, out of which 11.5 million $\mathrm{m}^{3}$ was exported. With export value amounting to $£ 2.3$ billion per annum (Skogs industrierna, 2010), sawmilling is one of the important part of Swedish economy (see Table 2).This section will thus discuss the major strategies that Swedish sawmilling undertook to maintain its production and export at increasing level. It will also discuss type of sawmilling industries that are currently in operation. 


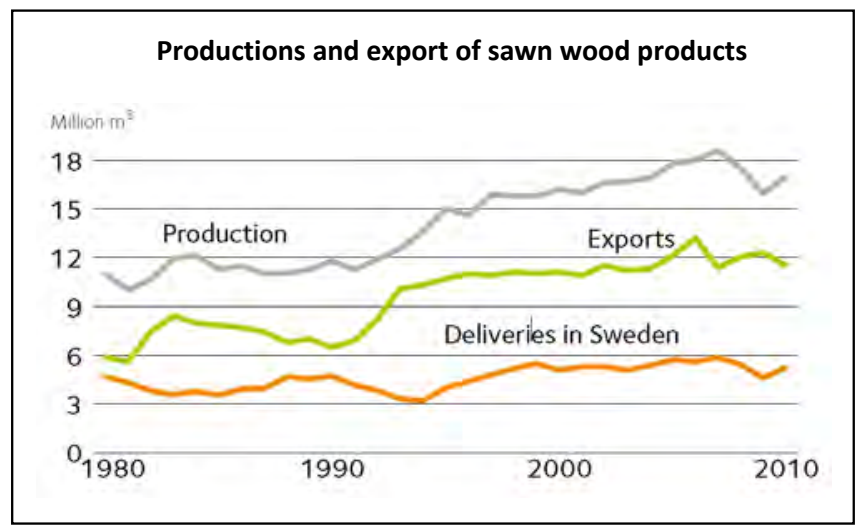

Figure 2: Trends of productions and export of sawn wood products in Sweden (Skogs industrierna, 2010)

Table 2: Swedish exports of Sawn and planed softwood

\begin{tabular}{|l|l|l|l|l|}
\hline \multicolumn{1}{|c|}{$\begin{array}{c}\text { Importing } \\
\text { region }\end{array}$} & \multicolumn{1}{|c|}{$\begin{array}{c}\text { Quantity } \\
\text { (in 1000:s } \mathbf{~ m}^{3} \text { ) }\end{array}$} & \multicolumn{1}{|c|}{$\begin{array}{c}\text { Value } \\
\text { (SEK 1000s) }\end{array}$} & $\begin{array}{c}\text { Shared quan- } \\
\text { tity (\%) }\end{array}$ & $\begin{array}{c}\text { Share of value } \\
(\mathbf{\%})\end{array}$ \\
\hline Europe & 8455 & 16073871 & 69 & 70 \\
\hline EU & 7613 & 14111444 & 62 & 61 \\
\hline Africa & 2357 & 4008868 & 19 & 17 \\
\hline Asia & 1287 & 2673224 & 11 & 12 \\
\hline Total & 12252 & 23103596 & 100 & 100 \\
\hline
\end{tabular}

Source: (Skogs industrierna, 2010)

\section{Strategies undertaken by sawmill industries in last two decades}

The industry's strategies during the past couple of decades have aimed to increase the degree of processing and value addition of the final products. With the increasing labour and raw material costs, mechanization and value addition were the strategies that were undertaken in last two decades. These strategies were implemented by establishing close contact with its customers in the European market and understanding their views (Blomsrom \& Ari, 2002). Hugosson and McCluskey (2008) list three major strategic transformations that they argue were observed in Swedish sawmilling sector from 1990 to 2005. They are:

Market channel strategy transformation: Myopic to warning signals due to perceived "filtering" of information by the sector's market channel middlemen, the sector's results were hit by an "unexpected" downturn in the early 1990s. This triggered a break with traditional middlemen and firms built their own marketing capabilities, establishing direct relationships with customers. This result contributes an understanding of the empirically indicated phenomenon of "the agent is dead". 
Product value adding strategy transformation: In the mid-1990s, using customer information that the sector had recently gained direct access to, the sector transformed its goods from wet commodities to specified goods that were of higher value to customers. This involved firms enhancing their production capabilities. Firms acted in tune with, and in some cases with foresight of, emerging environmental turbulence. This result contributes an understanding of the empirically indicated phenomenon of increased product processing.

Service value adding strategy transformation: Perceiving new business opportunities, firms enhanced their distribution logistics capabilities to offer customers specific logistics and distribution services - not just products. This started around the year 2000 and such new services are currently diffusing to customers. Firms acted with foresight to generate services in awareness of general environmental discussions about supply chain management possibilities. This result contributes an understanding of the empirically indicated phenomenon of focus on distribution logistics.

\section{Types of sawmill industries in Sweden}

As already discussed above the Swedish sawmills are increasing their application of value-adding process in their sawn-wood production. According to Roos et. al (2010), the sawmilling in Sweden can be divided into nine clusters with regard to the level and types of value-adding technologies. Table 2 gives the detail of the clusters/groups that exists in Sweden. 


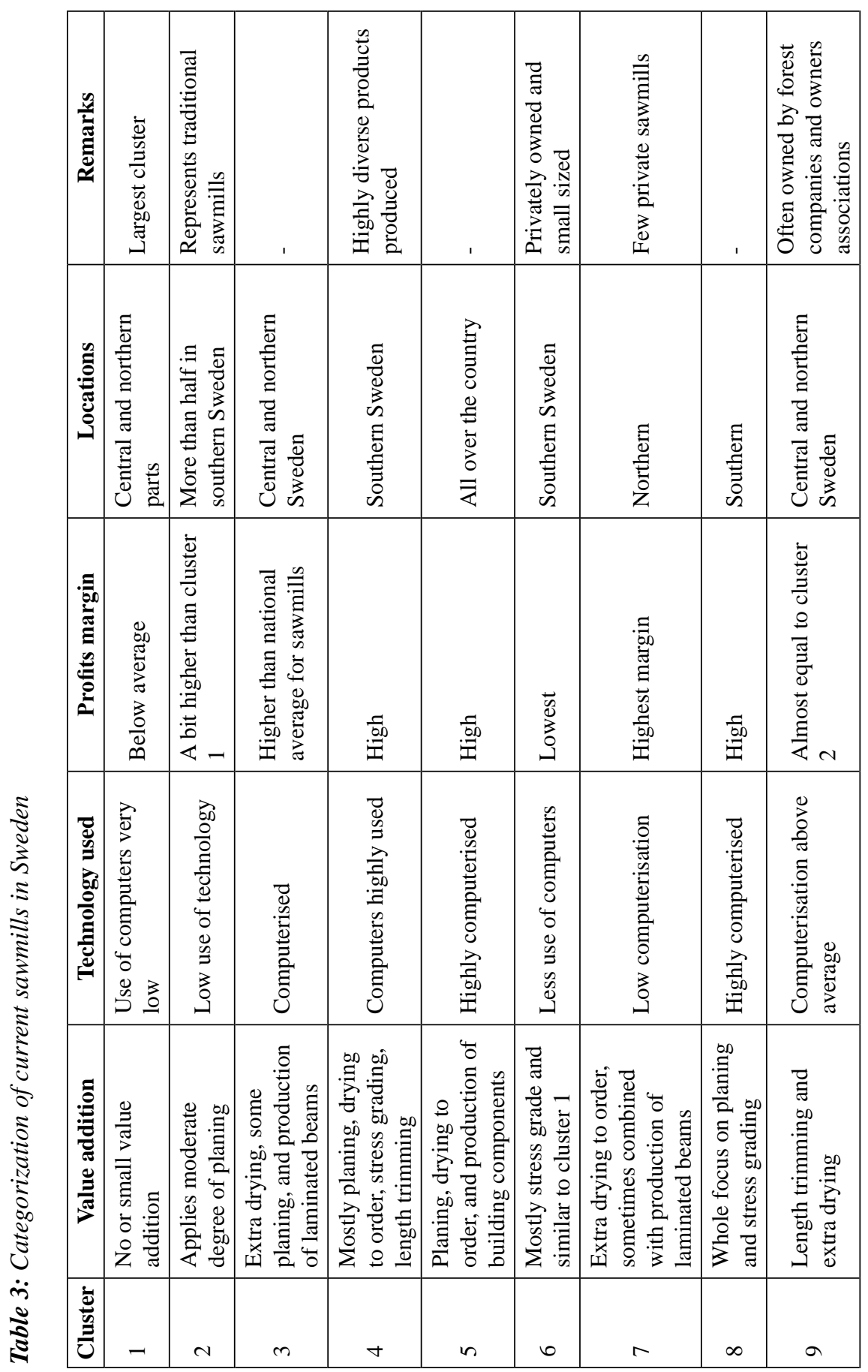




\section{Some of the existing issues of sawmilling industriesin Sweden}

This section will try to discuss some of the major issues that sawmilling industries in Sweden face and strategies that have been applied to overcome the challenges.

\section{Competition from other materials and nations:}

Youngqvist \& Hamilton (2000) reports that international competition from other materials (e.g. concrete, steel and plastics) and from other nations is increasing, especially for commodity sawn wood. Until the early 1990s, wood was used for about $90 \%$ of single-family houses, whereas larger buildings were generally constructed with steel and concrete structures. This trend can be exemplified by the building sector, where wood materials for a long period have been losing market shares to competing materials (Wiklund, 1992; Baudin, 1989).

In recent years, Chile, Brazil, Indonesia and China have emerged as the new competitors in the market. This may depress prices and reduce the profitability of Swedish production.

\section{Efficiency of technology and knowledge transfer}

Around 100 institutions and organizations are involved in technology and knowledge transfer in Sweden (Ds, 1991). However, efficiency in technology and knowledge transfer isyet considered inefficient as too little resources were spent on dissemination, particularly taking into account fragmented nature of the industry. Furthermore, many firms were not able to absorb the information provided by these organizations. In fact it was claimed that the main structural weakness of the entire sawn wood products group was a shortage of academically educated staff in sawmills and other firms. Sawn wood industry lacks organizations that are actively involved in the transfer of skilled personnel from universities and other research centres to the industry (Blomsrom \& Ari, 2002).

\section{Small scale sawmilling:}

Larger sawmills are often integrated with plants producing pulp, building joinery, or wooden houses, and they are concentrated. These have led forest owners to join cooperatives and sales organization to get equal bargaining power with timber buyers i.e. large timber buyers. This inhibits smaller independent sawmills, who have to confront monopolistic sellers with high raw material prices and unfavourable contracts (Blomsrom \& Ari, 2002). In addition to that, it is difficult to mechanize operations and introduce rational harvesting methods in small forest firms (UN, 1986). Small sawmills which are around 2000 in numbers may face the challenge of extinction.

\section{Lack of product diversification and specialized production}

As claimed by Rooset. al. (2010), sawmills with low degree of differentiation (for eg. Cluster 1 and 2 in Table 3) will encounter stiffer competition in the future from countries offering 
low cost products. Similarly, firms producing specific goods, as in case of cluster 9 (see Table 2) producing only trimmed sawn wood, might not produce high profit thus risking the operation of the industry. However, this issue is relevant to firms that are producing specific products.

\section{Future of sawmilling in Sweden}

Global demand for wood products is expected to continue to grow, in line with the growth in population and income, mainly in China, India and other developing countries. Predicting the production and consumption of sawn wood products in the globe for next 20 years show that the future of Swedish sawmills is bright provided it sheds its commodity orientation and increases the value-added by accommodating the growing demand for factory-made, energy-efficient construction components, as expressed by Green Building, for instance (Jonsson et. al, 2011). Also, the Swedish solid wood-product industry is not facing the same direct threat from globalization as the pulp and paper industry, since the expansion in the southern hemisphere is focused on pulp and paper production (Whiteman, 2005). Furthermore, Jonsson et. al, (2011) confirms that the development of prominent bioenergy markets should mainly benefit the sawmill industry, by obtaining higher prices for coproducts with limited competition from bio energy markets for raw materials. However, following strategies seems to be major future strategies in Swedish sawmilling industry.

\section{Encouraging the use of wood "Green building"}

It has been noted that wooden structures are commonly used for much larger buildings up to six stories high - in the US and Canada. Thus, it can be encouraged in the European market too. In addition to that stress graded wood products and the development of gluelaminating, edge-jointing, and finger-jointing techniques have raised the use of wood for this type of demanding construction purposes also in Scandinavia (Blomsrom \& Ari, 2002).

\section{Skill and knowledge transfer}

As discussed in section 4, there exists the problem in knowledge and skill transfer in sawmilling industry. In the paper and pulp industry, this problem is alleviated through the operations of thePulp and Paper Research Institute, which recruits engineers as "trainees" during times when industry demand is low. This does not only stabilize the labour market for skilled labour, but it also improves the connections between research organizations and pulp and paper companies.Consequently, a major challenge for the sawn wood products cluster is to set up a similar arrangement, with the Institute for Wood Technology Research filling the void (Blomsrom \& Ari, 2002).

\section{Increasing the size of the firm}

The average sawmill size is increasing in many countries to economise on fixed investments, e.g. in energy production, logistics, management and marketing(Stier \& Bengston, 1992; Bigsby, 1994; Warensjo, 1997). Production of sawn softwood increased in Sweden by 37\% 
between 1979 and 1995 whereas the number of sawmills decreased from 1015 to 726, implying that the size of the average sawmill almost doubled(Roos et. al, 2010). Thus, seeking the possibility for merging small scale sawmills can save them from being out of the business.

\section{Product diversification or value added strategy}

It has often been concluded that further processing of the sawn wood and better adaptation of the products to special market needs are necessary for the success of the industry (Cohen $\&$ Sinclair, 1992). This diversification dimension involves several measures, such as faster and more exact lengths according to customer needs, planning, extra drying, production of components to the building sector, and production of engineered wood. Swedish sawmills are adopting this approach and consequently the share of value-added lumber in the industry is increasing (Warensjo, 1997). For that industries will need to develop the ability to recognize and respond to new types of demand and competition - and get involved in active product and process development. Thus product diversification and value addition will be important key words in the Swedish sawmilling for future as well.

\section{Improved technology and mechanization}

Increasing labour productivity aiming at lowering unit labour costs is another important strategy dimension. Mechanisation, reduction of manual work, more computers and automatisation reduce the manpower needs and increase labour productivity. In Sweden, this process has been engendered by increasing labour costs since the 1970s. With increase in labour cost mechanisation and automatisation should be continuous strategy.

\section{Summary}

With huge forest resources, Sweden is the second largest combined exporter of the paper, pulp and sawn wood timber in the world. Sawmilling plays a very significant role in its economy. The liberalization of British sawn timber import, and downturn of Norwegian export due to short supplies and expensive timber of Canada, boosted the development of Swedish sawmilling in mid-19 ${ }^{\text {th }}$ Century. It faced many crises since then and it mainly affected small sawmills forcing them to leave the business and compelling large sawmills to undertake integrated approach. Since 1970s, the industry has undertaken value addition strategy to keep its business running. In the early 1990s industry took another major strategy of eliminating middle man and in the early 2000s service value addition was introduced. This has secured the future of sawmills of Sweden. Regarding the future, sawmilling has brighter future than other wood industries due to focus of world on 'green building'. In addition to that development of prominent bio-energy markets will benefit the sawmill industry. Some of the major issues that this industry should take into consideration for better future include encouraging 'green building', developing strategies to transfer skills and knowledge, increasing the size of firms, further value addition and product diversification, and introduction of advance mechanization. 


\section{Reffernces}

Baudin, A. 1989. Den svenska tr avarumarknaden-del. Uppsala: The Swedish University of Agricultural Sciences. Department of Forest-Industry-Market Studies.

Bigsby, H. R. 1994. Production structure and the Australian sawmilling industry. Australian Journal of Agricultural Economics, 28(3), 271-288.

Blomsrom, M., \& Ari, K. 2002. From natural resources to high-tech production: the evolution of industrial competitiveness in Sweden and Finland. Stockholom: Stockholm School of Economics.

Cohen, D. H., \& Sinclair, S. A. 1992. 1992. Forest products Journal, 42, 40-44.

Ds. 1991. Kunskap för konkurrenskraft - skogsindustrins kunskapsförsörjning. Stockholm: Minsitry of Industry.

FAO. 2010. Global Forest Resource Assessment 2010: Country Report of Sweden. Rome: Food and Agriculture Organization.

Hallvarsson, M. 1980. Industrialismens 100 ar. Stockholm : Sveriges Industriförbunds Förlag.

Hugosson, M. \& McCluskey, D. 2008. Strategic transformations of the Swedish sawmill sector 1990-2005.Studia ForestaliaSuecia, 217.33 pp. ISSN 0039-3150, ISBN 978-91 -85911-96-7.

Jonsson, R., Egnell, G., \& Baudin, A. 2011. Swedish forest sector outlook study. Geneva: United Nations Economic Commission for Europe/Food and Agriculture Organization of the United Nations.

Larson, M. 1991. En svensk ekonomisk historica 1850-1985. Stockholm: SNS Forlag.

Roos, A., Flinkman, M., Jappinen, A., Lonner, G., \& Warensjo, M. 2010. Identification of Value adding Strategies in the Swedish Sawn Wood Industry. Scandinavian Journal of Forest research, 17(1), 90-96.

Skogs indusrierna. 1994. A Search for Sustainable Forestry - the Swedish view, Annual publication. Stockholm: The Swedish Pulp and Paper Association.

Skogs industrierna. 2010. The Swedish forest industries: Facts and figures 2010. Swedish Forest Industries Federation.

Stier, J. C., \& Bengston, D. N. 1992. Technical change in the North American Forestry sector: A review. Forest Science, 38(1), 134-159. 
Svensen, M. 1992. "Skogsindustri”, in Sveriges industri, Industriförbundet. Stockholm.

UN. 1986. European Timber Trends and Prospects to the year 2000 and beyond. New York: United Nations.

Warensjo, M. 1997. S ${ }^{\circ}$ ag 95-Del 1. Sveriges Lantbruksuniversitet. Institutionen for Virkesl"ara.

Whiteman, A. 2005. Recent Trends and Developments in Global Markets for Pulp and Paper. Presented at Paperex 2005 - International Technical Conference on Pulp and Paper Industry. New Delhi, December.

Wiklund, M. 1992. Lonsam tratradition-Bedomningar ur ett skogspolitiskt perspektiv av produkter och teknik i tramekanisk industri. SOU, 76.

Youngqvist, J. A., \& Hamilton, T. E. 2000. A look at the world's timber resources and processing facilities. In B. Krishnapilly, R. Jandl, M. Devall, M. Khorchidi, E. Schimpt, \& G. Wolfrum, Proceedings of the XXI IUFRO World Congress in Kuala Lumpur (Vol. 11, pp. 183-194). Kuala Lumpur, Malaysia. 